\title{
Social Economic Impact of Microfinance for Women Empowerment (Comparison Analyses in Kosovo and Bosnia and Herzegovina as Post Conflict Countries)
}

\author{
Phd. Cand. Qefsere Kupina \\ PhD Candidate - European University of Tirana; Email:qefsere@gmail.com \\ Prof. Dr. Drini Salko \\ Lector on Faculty of Economy and Agribusiness, Agricultural University of Tirana \\ Email:drinisalko61@gmail.com
}

Doi:10.5901/ajis.2015.v4n3s1p632

\begin{abstract}
Microcredit program is positioned with a potential to transform power relations and empower the poor-both men and women. Increasing up to 3652 microfinance institutions, by reaching about 205.3million clients, from which about 153mil are women, is a very promising progress. While, conflicts cause degradation of both quality of life and economic situation, presence of microfinance institutions was necessary. Microfinance is often hailed both as a tool for fighting poverty and as a tool for post conflict reconciliation. With such weight we say that the functioning and contributions of microfinance institutions have been necessary also in Kosovo, after the war ended in 1999. The impact and almost positive role of microfinance is the obvious in post-conflicts countries where this industry has developed. Therefore, the aim of this paper is focused to see the case in Kosovo, in comparison with the case in Bosnia and Hercegovina, in participating women as a client to microfinance institution. As overall the paper describes the role of importance of microfinance institutions since its established, including in the post conflict countries by focusing on women as responsible client of selected MFIs. By this, we say that the functioning and the contribution of microfinance institutions have been necessary and effective in Kosovo onward, this because of the role of women can have in society especially after the war ended. After work with data, will bring a picture about the number of women as borrowers in MFI in two countries, some remarks at the end of the paper will contribute.
\end{abstract}

Keywords: microfinance, empowerment, women, post conflict countries.

\section{Introduction}

Conflicts cause degradation of both quality of life and economic situation ${ }^{1}$. Post conflict countries to recoveries an overall sustainable situation and continue with development in all scopes of life, numbers of difficulties have to overcome. In such cases as Das (2003) states, it is important for the microfinance institutions, to adapt to the transition and evolving political, social and economic changes that occur. Therefore, in such cases there are opportunities to contribute through studies, with effects on further progress.

Kosovo and Bosnia and Herzegovina are countries with a comparable history. Both countries were part of former Yugoslavia², until the armed conflict explodes in 1992 to 1995 in Bosnia and Herzegovina and 1998 until 1999 in Kosovo. Two systems within their priority after the conflict ended are very similar in regard of reconstruction and rebuilding the financial system.

In Bosnia and Herzegovina after the conflict ended, damages were numerous. Several households are affected in destruction of financial, physical, human and social assets, leading to significant increase in household vulnerability to risk (Matul and Tsilkouns) ${ }^{3}$. Because, microfinance is often hailed both as a tool for fighting poverty ${ }^{4}$ and as a tool for

\footnotetext{
${ }_{1}$ Welle-Strand, A., Sitter, N., \& Kjøllesdal, K. (2010).

${ }_{2}$ See about, RSFJ-Jugosllavia

${ }_{3}$ Matul, M., \& Tsilikounas, C. (2004). Role of microfinance in the household reconstruction process in Bosnia and Herzegovina. Journal of International Development, 16(3), 429-466.

4 "microfinance is certainly not a panacea for poverty, it can prove itself a useful tool in the fight against poverty"(Kirsten Leikem,2012)
} 
post-conflict reconciliation ${ }^{5}$, it is stated that $\mathrm{BH}$ can be taken as "best-case scenario for testing the impact of microfinance's" (Strand and Kjollesdal,2010).

Kosovo, after 1999 characterized by massive destruction almost in all spheres of development, by not excluding incurred losses in human aspect. Thus, support and the need for capital project for restructuring, economy, social and political development were inescapable. International community, organized to establish order and security and avert of post- conflict consequences. These consequences, returns Kosovo in just start-up with banking system activities, with non existence of financial intermediation, and with the cash transactions settled. Therefore, fast development will happen, financial sector will show positive activities started with the beginning of year 2001. As one of priority, microfinance institutions (MFI) starting its operations as non-government organizations, supported by international donors, to continue with expansion and development as a part of the Kosovo financial sector.

Creation of the MFIs in post- conflict countries, NGOs and other development and humanitarian organizations should aim to use and accept local social norms and practices, before imposing 'imported' development, which often are driven by donors ${ }^{6}$. Therefore, by presenting the achievements of microfinance institutions in Kosovo after the war ended, the paper will be focused in more detail to see the trend of women approach to the microfinance institutions services that currently operates in Kosovo market. Thus, some comparison of the data from specific MFI in Bosnia Herzegovina and Kosovo will be analyzed. So, if this weight of microfinance has led to the empowerment of women in Kosovo with a conclusion and some remarks in the end of the paper will contribute.

\section{Literature Review}

The more, examined issue about poverty, the more emphasis is about the role of microfinance. The first idea, about how to help poor people, to escape from poverty, is considered as beginning on offering the microfinancial services. In this context the effort given by Professor Muhammad Yunus from Bangladesh, to come up with establishments of "Grameen Bank"7, which " serves as an inspiration for those trying to help poor and low-income people in their own efforts to improve their lives" 8 ."Grameen idea was reaching more and more families and communities every year"9.

Microcredit Summit (2012), in December 31, 2010 indicates that 3,652 microfinance institutions reported reaching $205,314,502$ clients. There are $137,547,441$ of who were among the poorest when they took their first loan. The highest number, of these poorest clients 82.3 percent, or $113,138,652$, is women ${ }^{10}$. Therefore, it is considered that, microfinance has provided important contributions to the development (Leike, 2012).

The impact and almost positive role of microfinance is the obvious in post-conflict countries where this industry has developed. This creates an idea that we have to deal with a productive instrument that poses special features. Microfinance is often considered both as a tool for fighting poverty and as a tool for post- conflict reconciliation ${ }^{11}$. MFIs in conflict affected countries have been presented in more commercial approaches to their growth, by following the example of normal environments of MFIs around the world ${ }^{12}$.

\section{Weight of the Microfinance for Women Empowerment}

In well-run microfinance programs, there is a relationship of respect between the institution and the client that is inherently empowering ${ }^{13}$. In addition, according to Hermes and Lensing (2011) targeting such group of client, is because, women often prove to be more financially responsible with better repayment performance than men ${ }^{14}$. They use substantial parts of their income for health and education of their children and play a very important role in reducing

\footnotetext{
${ }_{5}^{5}$ Welle-Strand, A., Sitter, N., \& Kjøllesdal, K. (2010). Assessing microfinance: the Bosnia and Herzegovina case.

${ }^{6}$ Das, N. (2003)

${ }^{7}$ http://www.grameen-info.org/grameen-founder-muhammad-yunus/

${ }^{8}$ David Hulme(2008)

${ }_{9}$ Yunus, M. (2007). Creating a world without poverty: Social business and the future of capitalism. PublicAffairs.

10 http://www.microcreditsummit.org/uploads/resource/document/web_socr-2012_english_62819.pdf

11 Welle-Strand, A., Sitter, N., \& Kjøllesdal, K. (2010

12 Kosovo Case Study: Linkages between Microfinance and Other Livelihood programs

${ }^{13}$ Cheston, S., \& Kuhn, L. (2002). Empowering women through microfinance.Draft, Opportunity International.

${ }_{14}$ Littlefield, E., Morduch, J., \& Hashemi, S. (2003). Is microfinance an effective strategy to reach the Millennium Development Goals?. Focus Note, 24(2003), 1-1
} 
poverty within households (Hermes and Lensik, 2011).

Access to finance contributes to an improvement of the social and economic situation of women. This may empower to become more confident, assertive, more likely to participate in family and community decision, and also prepared to confront systematic gender inequities ${ }^{15}$. Next to this, microfinance initiatives reduce poverty, promote education of children, improve health and empower women ${ }^{16}$. As well, microfinance programs have the potential to transform power relations and empower the poor-both men and women ${ }^{17}$.

The findings, stated from, Cheston and Kuhn, (2002) affirm the importance of designing appropriate products for women. This, based on a survey conducted in 2001 by the Special Unit on Microfinance of the United Nations Capital Development Fund (SUM/UNCDF) of 29 microfinance institutions revealed that approximately 60 percent of these institutions' clients were women. Six of the 29 focused entirely on women. Among the remaining 23 mixed-sex programs, 52 percent of clients were women. The study also showed, however, that those programs offering only individual loans or relatively high minimum loan amounts tended to have lower percentages of women clients ${ }^{18}$.

\section{Assessment of the Women as a Client with the Positive Performance}

There are many surveys about "targeting women as a client with better repayment performance". At the same time there are several studies about the importance and meaning the empowerment of women. By adding Sanyl (2009),"microfinance programs with group-based lending, and a near exclusive focus on women as loan clients, have become a globally popular antipoverty intervencion", while author argues, "microfinance groups have the potential to promote women's social capital and normative influence , thereby facilitating women's collective empowerment " 19 . In his paper about the "Impact of Micro Credit on women empowerment ", he emphasizes the meaning about the "empowerment "which is "a process of change by which individual or group gain power and ability to take control over their lives" and involves "growth of well being, access to resources, self-confidence, self-esteem and respect... and increased control over benefits and their own life"20.

Selecting four (4) MFIs per country (Bosnia and Herzegovina and Kosovo), by adding latest period from 20102013 (this because for other MFIs in both countries, were not all data available for our paper work ) considering number of clients on yearly bases. The age of MFI is selected, the status and outreach and the regulation including scale of MFI is considered the important data. This, to get a picture of the women position as a client within selected MFIs. While it is important to mention that for this modest comparison the data is used from "mixmarket.org". We consider that more advance analysis can be produced in using more extensive data in similar work.

Table 1 - MFIs in Bosnia and Herzegovina

\begin{tabular}{|c|c|c|c|c|c|c|c|c|c|c|c|c|c|c|c|}
\hline \multicolumn{16}{|c|}{ NUMBER OF CUENT / ACT NE BORROWER DUPING THE PEFIOD 2010-2013 -MFIIBosnia and Hercegouna } \\
\hline EKI & $\begin{array}{c}\text { Client } \\
\text { number }\end{array}$ & female & Male & Entity & $\% \mathrm{~F}$ & $\% \mathrm{M}$ & $\% \mathrm{E}$ & LOK Micr & \begin{tabular}{c|c} 
Client \\
number
\end{tabular} & female & Male & Entity & $\% \mathrm{~F}$ & $\% \mathrm{M}$ & $\%$ E \\
\hline 2010 & 41,605 & 17,116 & 24,289 & 200 & $41 \%$ & $58 \%$ & $0.5 \%$ & 2010 & 29,800 & 11,510 & 17,420 & 870 & $39 \%$ & $58 \%$ & $2.9 \%$ \\
\hline 2011 & 35,342 & 14,062 & 21,152 & 128 & $40 \%$ & $60 \%$ & $0.4 \%$ & 2011 & 23,546 & 8,300 & 13,837 & 1,409 & $35 \%$ & $59 \%$ & $6.0 \%$ \\
\hline 2012 & 33,987 & 13,232 & 20,644 & 111 & $39 \%$ & $61 \%$ & $0.3 \%$ & 2012 & 24,672 & 8,133 & 14,813 & 1,726 & $33 \%$ & $60 \%$ & $7.0 \%$ \\
\hline 2013 & 36,237 & 14,218 & 21,905 & 114 & $39 \%$ & $60 \%$ & $0.3 \%$ & 2013 & 19,101 & 6,818 & 10,619 & 1,664 & $36 \%$ & $56 \%$ & $87 \%$ \\
\hline & & & & & & & & & & & & & & & \\
\hline \begin{tabular}{|c|} 
MI \\
Bospo
\end{tabular} & $\begin{array}{c}\text { Client } \\
\text { number }\end{array}$ & female & Male & Entity & $\% \mathrm{~F}$ & $\% \mathrm{M}$ & $\% E$ & SUNRISE & $\begin{array}{c}\text { Client } \\
\text { number }\end{array}$ & female & Male & Entity & $\% \mathrm{~F}$ & $\% \mathrm{M}$ & $\% E$ \\
\hline 2010 & 16,195 & 16,195 & $\cdot$ & . & $100 \%$ & $0 \%$ & $0.0 \%$ & 2010 & 19,103 & 8,015 & 11,007 & 81 & $42 \%$ & $58 \%$ & $0.4 \%$ \\
\hline 2011 & 13,912 & 12,936 & 976 & . & $93 \%$ & $7 \%$ & $0.0 \%$ & 2011 & 15,262 & 6,245 & 8,888 & 129 & $41 \%$ & $58 \%$ & $0.8 \%$ \\
\hline 2012 & 14,172 & 12,173 & 1,999 & $\cdot$ & $86 \%$ & $14 \%$ & $0.0 \%$ & 2012 & 12,424 & 5,083 & 7,215 & 126 & $41 \%$ & $58 \%$ & $1.0 \%$ \\
\hline 2013 & 15,643 & 12,313 & 3,330 & . & $79 \%$ & $21 \%$ & $0.0 \%$ & 2013 & 11,635 & 4,882 & 6,674 & 79 & $42 \%$ & $57 \%$ & $0.7 \%$ \\
\hline
\end{tabular}

Note: MFI selected as per author's valuation (EKI, LOKmicr, MI BOSPO, SUN RISE)

\footnotetext{
15 Littlefield, E., Morduch, J., \& Hashemi, S. (2003). Is microfinance an effective strategy to reach the Millennium Development Goals?. Focus Note, 24(2003), 1-1

${ }^{16}$ Welle-Strand, A., Sitter, N., \& Kjøllesdal, K. (2010). Assessing microfinance: the Bosnia and Herzegovina case.

17 Cheston, S., \& Kuhn, L. (2002). Empowering women through microfinance.Draft, Opportunity International.

${ }_{18}$ Cheston, S., \& Kuhn, L. (2002). Empowering women through microfinance.Draft, Opportunity International.

19 Sanyal, Paromita. "From credit to collective action: The role of microfinance in promoting women's social capital and normative influence." American Sociological Review 74.4 (2009): 529-550.

${ }_{20}$ Malik, N. H., \& Luqman, M. (2005). Impact of Micro Credit on women empowerment: A review paper. Pak. J. Agri. Sci, 42, 3-4.
} 
Table 2.

PERSENTAGE OF female FROMTHE TOTAL NUMBER OF CLIENTS IN YEARLY BASES
\begin{tabular}{|c|c|r|r|r|r|r|r|}
\hline Year & EKI & $\begin{array}{c}\text { MI } \\
\text { BOSPO }\end{array}$ & LOK Micr & SUN RISE & Total Clients & Total female & $\%$ female \\
\hline 2010 & 41,605 & 16,195 & 29800 & 19103 & 106,703 & 52,836 & $50 \%$ \\
\hline 2011 & 35,342 & 13,912 & 23546 & 15262 & 88,062 & 41,543 & $47 \%$ \\
\hline 2012 & 33,987 & 14,172 & 24672 & 12424 & 85,255 & 38,621 & $45 \%$ \\
\hline 2013 & 36,237 & 15,643 & 19101 & 11635 & 82,616 & 38,231 & $46 \%$ \\
\hline
\end{tabular}

\begin{tabular}{|c|c|c|c|c|}
\hline \multicolumn{5}{|c|}{ Trend on MFIs client/women - BiH } \\
\hline 100,000 & 52,836 & 41,543 & 38,621 & 38,231 \\
\hline & 2010 & 2011 & 2012 & 2013 \\
\hline
\end{tabular}

Table 3.

\begin{tabular}{|c|c|c|c|c|c|c|c|c|c|c|c|c|c|c|c|}
\hline \multicolumn{16}{|c|}{ NUMBER OF O_IENT IACT ME BORROWER DURING THEPERIOD 2010 - 2013 - MFI in KOSOVO } \\
\hline FINCA & $\begin{array}{c}\text { Client } \\
\text { number }\end{array}$ & female & Male & Entity & $\% \mathrm{~F}$ & $\% \mathrm{M}$ & $\% \mathrm{E}$ & AFK & \begin{tabular}{c|} 
Client \\
number
\end{tabular} & female & Male & Entity & $\% \mathrm{~F}$ & $\% \mathrm{M}$ & $\% \mathrm{E}$ \\
\hline 2010 & 16,581 & 3,257 & 13,324 & & $20 \%$ & $80 \%$ & $0.0 \%$ & 2010 & 4603 & 1015 & 3588 & & $22 \%$ & $78 \%$ & $0.0 \%$ \\
\hline 2011 & 13281 & 10,723 & 2558 & & $81 \%$ & $19 \%$ & $0.0 \%$ & 2011 & 5192 & 1215 & 3977 & & $23 \%$ & $77 \%$ & $0.0 \%$ \\
\hline 2012 & 10,520 & 2,009 & 8511 & & $19 \%$ & $81 \%$ & $0.0 \%$ & 2012 & 6410 & 1456 & 4954 & & $23 \%$ & $77 \%$ & $0.0 \%$ \\
\hline 2013 & 11,424 & 2,198 & 9,226 & & $19 \%$ & $81 \%$ & $0.0 \%$ & 2013 & 7695 & 177 & 5742 & 176 & $23 \%$ & $75 \%$ & $2.3 \%$ \\
\hline
\end{tabular}

\begin{tabular}{|c|c|c|c|c|c|c|c|c|c|c|c|c|c|c|c|}
\hline KEP & $\begin{array}{c}\text { Client } \\
\text { number }\end{array}$ & female & Male & Entity & $\% F$ & $\% \mathrm{M}$ & $\% \mathrm{E}$ & KGMAMF & \begin{tabular}{|c|} 
Client \\
number
\end{tabular} & Femal & Male & Entity & $\% \mathrm{~F}$ & $\% \mathrm{M}$ & $\% \mathrm{E}$ \\
\hline 2010 & 21,083 & 7,414 & 11513 & 2,156 & $100 \%$ & $0 \%$ & $0.0 \%$ & 2010 & 4868 & & 4868 & & $0 \%$ & $100 \%$ & $0.0 \%$ \\
\hline 2011 & 17,100 & 5,642 & 9855 & 1,603 & $93 \%$ & $7 \%$ & $0.0 \%$ & 2011 & 4703 & 4703 & 0 & & $100 \%$ & $0 \%$ & $0.0 \%$ \\
\hline 2012 & 14,960 & 4,407 & 9,651 & 902 & $86 \%$ & $14 \%$ & $0.0 \%$ & 2012 & 4809 & 1456 & 3353 & & $30 \%$ & $70 \%$ & $0.0 \%$ \\
\hline 2013 & 13,364 & 9,607 & 349 & 3408 & $79 \%$ & $21 \%$ & $0.0 \%$ & 2013 & 4815 & 4809 & 6 & 176 & $100 \%$ & $0 \%$ & $3.7 \%$ \\
\hline
\end{tabular}

Note: MFI selected as per author's valuation (FINCA, AFK,KEP,KGMAMF)

Table 4.

PERSENTAGE OF female FROM THE TOTAL NUMBER OF CLIENTS IN YEARLY BASES

\begin{tabular}{|r|r|r|r|r|r|r|r|}
\hline & \multicolumn{1}{|c|}{ FINCA } & \multicolumn{1}{c|}{ KEP } & \multicolumn{1}{c|}{ AFK } & \multicolumn{1}{c}{ KGMAMF } & \multicolumn{1}{c|}{ Total Clients } & Total female & \% women \\
\hline 2010 & 16,581 & 21,083 & 1015 & 4868 & 43,547 & 11,686 & $27 \%$ \\
\hline 2011 & 13,281 & 17,100 & 1215 & 4703 & 36,299 & 22,283 & $61 \%$ \\
\hline 2012 & 10,520 & 14,960 & 1456 & 4809 & 31,745 & 9,328 & $29 \%$ \\
\hline 2013 & 11,424 & 13,364 & 1777 & 4815 & 31,380 & 18,391 & $59 \%$ \\
\hline
\end{tabular}

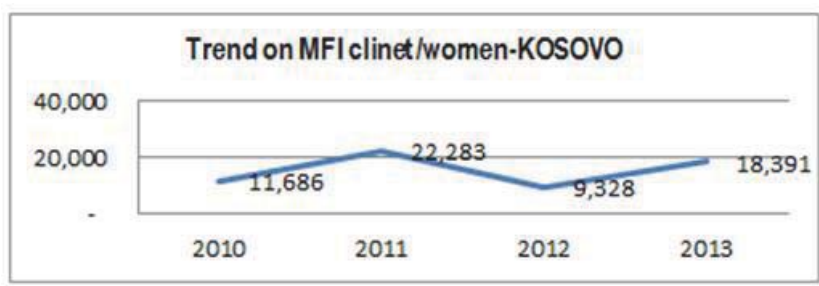

According to the latest statistics the percentage of women participations within the MFI in Kosovo and BH is about $27 \%$ in 2010 by increasing in about $59 \%$ or $6 \mathrm{k}$ clients more, and $50 \%$ in 2010 by decreasing in $46 \%$ in 2013 , respectively. This shows some difference between two similar environments but having in mind that functioning of MFIs started earlier in $\mathrm{BiH}$ and their banking and loan culture amongst its citizens was a quite higher level of understanding before the war 
started then we can conclude that this is one of the reason for the mentioned difference. At the same time one good sign for Kosovo during the later years of 2011-2013 is the steady rise in the women recipients of these loans which show growing trust of MFIs towards them.

\section{Conclusion and Some Remarks}

As per, above paper describe the role of importance of microfinance institutions since it's established, including in the post conflict countries by focusing on women as responsible client of selected MFIs, we say that the functioning and the contribution of microfinance institutions have been necessary and effective in Kosovo onward, this because of the role of women can have in society especially after the war ended.

The main fact that is related to our paper is the numbers of women take part as borrowers in Microfinance institution, which can be considered that in the future this number of women as a MFIs client can be increased. As well it shows that the women themselves are showing more confidence in their own abilities and see themselves as somebody who can take direct decision in helping family to get out of poverty with their acumen for business.

In the framework of supporting small business, it is necessary for Kosovo government budget, to determine a fund on support to women's entrepreneurship. Such fund should be coordinated with financial projects for a woman's entrepreneurial, that the microcredit programs or donor projects have.

\section{Refereces}

Cheston, S., \& Kuhn, L. (2002). Empowering women through microfinance.Draft, Opportunity International

Hermes, N., \& Lensink, R. (2011). Microfinance: its impact, outreach, and sustainability. World development, 39(6), 875-881.

Hulme, D. (2008). The Story of the Grameen Bank: From subsidised microcredit to market-based microfinance. Brooks World Poverty Institute Working Paper, (60).

Littlefield, E., Morduch, J., \& Hashemi, S. (2003). Is microfinance an effective strategy to reach the Millennium Development Goals?. Focus Note, 24(2003), 1-1

Leikem, K. (2012). Microfinance: A Tool for Poverty Reduction?.

Matul, M., \& Tsilikounas, C. (2004). Role of microfinance in the household reconstruction process in Bosnia and Herzegovina. Journal of International Development, 16(3), 429-466.

Malik, N. H., \& Luqman, M. (2005). Impact of Micro Credit on women empowerment: A review paper. Pak. J. Agri. Sci, 42, 3-4.

Sanyal, Paromita. "From credit to collective action: The role of microfinance in promoting women's social capital and normative influence." American Sociological Review 74.4 (2009): 529-550

Yunus, M. (2007). Creating a world without poverty: Social business and the future of capitalism. PublicAffairs.

Welle-Strand, A., Sitter, N., \& Kjøllesdal, K. (2010). Assessing microfinance: the Bosnia and Herzegovina case.

Kosovo Case Study: Linkages between Microfinance and Other Livelihood programs

http://www.microcreditsummit.org/uploads/resource/document/web_socr-2012_english_62819.pd

http://www.grameen-info.org/grameen-founder-muhammad-yunus/ 